\title{
Antioxidant and antifungal activities of extracts and condensed tannins from Stryphnodendron obovatum Benth.
}

\author{
Andréia Cristina Conegero Sanches ${ }^{1}$, Gisely Cristiny Lopes², Celso Vataru Nakamura², Benedito \\ Prado Dias Filho ${ }^{2}$, João Carlos Palazzo de Mello ${ }^{*}$
}

\author{
${ }^{1}$ Centro de Ciências Médicas e Farmacêuticas, UNIOESTE, '2Departamento de Farmácia e Farmacologia, \\ Universidade Estadual de Maringá
}

\footnotetext{
Correspondence:

J. C. P. Mello

Departamento de Farmácia e

Farmacologia

Universidade Estadual de Maringá

Av. Colombo, 5790

87020-900, Maringá-PR

E-mail:mello@uem.br
}

\begin{abstract}
The antioxidant activity of stem-bark extracts from Stryphnodendron obovatum Benth., including fractions and isolated compounds, was evaluated by DPPH in thin-layer chromatography. All the fractions and isolated compounds showed antioxidant activity. Antifungal activity was determined by the minimum inhibitory concentration (MIC) and minimum fungicidal concentration (MFC) against the yeasts Candida albicans, Candida parapsilosis, Candida krusei and Candida tropicalis. All extracts (CE, EtOAc and FW), subfractions (F1-F12) and the compounds I, II and III were inactive against the yeasts. Against C. parapsilosis and $\mathrm{C}$. albicans, fractions F13-15 and F20 showed moderate antifungal activity, and fractions F16-19 and F21-22 showed good activity. Chemical isolation of the ethyl-acetate fraction resulted in the identification of three compounds: epigallocatechin, gallocatechin and epigallocatechin- $(4 \beta \rightarrow 8)$-gallocatechin.
\end{abstract}

\author{
Uniterms \\ - Stryphnodendron \\ obovatum \\ - Leguminosae \\ - Antioxidant activity \\ - Antifungal activity \\ - Condensed tannins
}

\section{INTRODUCTION}

The genus Stryphnodendron Mart., family Leguminosae, includes about 48 species, all native to central savannas of Brazil, including Stryphnodendron obovatum Benth. (Cronquist, 1988). The stem bark of several species of Stryphnodendron, which contains about $20 \%$ tannins, is used by the local population for wound healing and treatment of leukorrhea and diarrhoea (Santos and Mello, 2004). Tannin-rich plants are used in folk medicine because of their antimicrobial properties, and act as scavengers of free radicals (Santos and Mello, 2004).

The search for compounds with antimicrobial activity is urgent and indispensable for the treatment of infectious diseases caused by microorganisms resistant to traditional antimicrobial drugs (Irobi et al., 1994). For this reason, Toledo (2002) and Lopes et al. (2003) evaluated the antimicrobial activity of crude extracts and fractions isolated from two other species of Stryphnodendron $[S$. adstringens (Mart.) Coville and S. polyphyllum Mart.]; both species showed good activity. Simeray et al. (1982) and Foo et al. (2000) also reported antimicrobial activity of tannins present in different species.

The anticarcinogenic and antimutagenic potentials of tannins may be related to their antioxidative properties important in preventing cellular oxidative damage, including lipid peroxidation (Haslam, 1998). Okamura et al. 
(1993), Bors et al. (2000), Demirezer et al. (2001) and Velázquez et al. (2003) demonstrated the antioxidant activity of extracts and tannins isolated from red wine, Eucalyptus rostrata Schltdl., Camellia sinensis (L.) Kuntze, Rumex patientia L., Aristolochia giberi Hook, Schinus weinmannifolia Engler, and Piper fulvescens DC.

The aim of the present investigation was to evaluate the antioxidant and antifungal activities of extracts, fractions and compounds isolated from S. obovatum. This is the first time that chemical and biological activities have been evaluated in this species of plant.

\section{MATERIAL AND METHODS}

\section{Plant material}

The stem bark of Stryphnodendron obovatum Benth was collected in the city of Assis, state of São Paulo (22³5'20.8''S; 50²4'18.7' 'W; 546 m altitude) in February 2001. The plant was identified by Prof. Dr. Cássia Mônica Sakuragui. A voucher specimen is deposited in the Herbarium of the Biology Department, State University of Maringá, Brazil (HUM 8137).

\section{Extraction and isolation}

The stem bark (700 g) was submitted to turboextraction with acetone-water $(7: 3 \mathrm{v} / \mathrm{v})$ for $30 \mathrm{~min}$, yielding a crude extract (CE). The CE (100 g) was partitioned with a mixture of ethyl-acetate/water $(1: 1,12$ times), resulting in aqueous (FW, $70.5 \mathrm{~g}$ ) and ethylacetate (EtOAc, $17.9 \mathrm{~g}$ ) fractions. A $10 \mathrm{~g}$ subsample of the EtOAc was subjected to column chromatography on Sephadex ${ }^{\circledR}$ LH-20 with an eluent gradient between EtOH and water $(1: 1)$ and EtOH $(100 \%)$, to yield 22 subfractions (F1 to F22). Subfractions F8 and F10 were rechromatographed under the same conditions, yielding 3 compounds which were identified by NMR (Varian Mercury Plus BB, $300 \mathrm{MHz})\left({ }^{1} \mathrm{H},{ }^{1} \mathrm{H} /{ }^{1} \mathrm{H}\right.$ COSY$)$, and mass spectroscopy (ESI-MS, Quattro LCZ Micromass, Manchester, UK) and polarimetry (Perkin Elmer Polarimeter 241). The compounds were identified as epigallocatechin (I) (31.8 mg) and gallocatechin (II) (17.1 $\mathrm{mg}$ ), by comparison with data in the literature (Mello et al., 1996).

Compound III (13.9 mg), after derivatisation, showed the following data of ${ }^{1} \mathrm{H} \mathrm{RMN}\left(\mathrm{CDCl}_{3}\right)$ : the MS supplied to the pseudo-molecular ion $[\mathrm{M}+\mathrm{H}+]+$ in $m / z 611.2(19 \%)$ and the peak base in $\mathrm{m} / \mathrm{z} 305.0(100 \%)$.

\section{Antioxidant Activity}

Antioxidant activity was determined by thin-layer chromatograph DPPH (1,1-diphenyl-2-picrylhydrazyl) radical at $0.2 \%$ in $\mathrm{MeOH}$ direct by TLC, as recommended by Cuendt et al. (1997) and Hostettmann et al. (2003). Solutions of the crude extract, the ethyl-acetate fraction, and all the subfractions were all tested at a concentration of $100 \mu \mathrm{g} / \mathrm{ml}$. The compounds isolated were tested at a concentration of $10 \mu \mathrm{g} / \mathrm{ml}$. The reference drugs astilbin, gallic acid, quercetin and rutin (Sigma Chemical Co., St. Louis, Missouri, USA) were prepared at a concentration of $10 \mu \mathrm{g} / \mathrm{ml}$.

\section{Antifungal Activity}

Antifungal activity of the crude extract, fractions, all subfractions, and isolated compounds was evaluated by the method of microdilution in broth (NCCLS, 2002), determining the minimum inhibitory concentration (MIC) and the minimum fungicidal concentration (MFC). The yeasts used were strains of Candida albicans (ATCC 573), and Candida parapsilosis, Candida tropicalis and Candida krusei obtained from clinical samples. Nystatin (Sigma) was used as the reference drug.

\section{RESULTS AND DISCUSSION}

The crude extract (CE) partitioned with ethyl-acetate/ water resulted in the fractions ethyl-acetate (EtOAc) and aqueous (FW). The EtOAc fraction was separated on Sephadex ${ }^{\circledR}$ LH-20 column in 22 subfractions (F1-F22).

Because of the high tannin concentration in the bark of $S$. obovatum (13 - 19\%) in the bark of S. obovatum (Sanches et al., 2002) and in view of literature data indicating that tannins may have antioxidant activity because of their capacity to scavenge radicals (Santos and Mello, 2004), the CE, the fractions (EtOAc and FW), and the chromatographic subfractions were analysed by their ability to scavenge DPPH. The results demonstrated the capacity of the CE, the EtOAc and FW fractions and the subfractions (F1-F12) to reduce the DPPH radical. In particular, the subfractions F5-F12, at concentrations of $100 \mu \mathrm{g} / \mathrm{ml}$, showed high antioxidant activity compared to quercetin, rutin, gallic acid and astilbin controls (Fig. 1). The subfractions F13-F22 were not analysed.

These results have been confirmed by other investigators. Okamura et al. (1993) demonstrated that tannins present in Eucalyptus sp. have potential antioxidant activity. Bors et al. (2000) demonstrated the antioxidant activity of proanthocyanidins and hydrolysable 
tannins in red wine and green tea. Hatano et al. (2002) studied the inhibitory effect of NADP-dependent lipid peroxidation, besides the effect of inhibiting the autoxidation of linoleic acid; these effects were attributed to the scavenging activity of radicals, based on results from cacao polyphenols.

The crude extract (CE), the fractions (EtOAc and FW) and the subfractions (F1-F22) were also analysed by their antifungal activity against $C$. albicans, $C$. parapsilosis, C. krusei and C. tropicalis. The results show values of MIC and MFC $>1,000 \mu \mathrm{g} / \mathrm{ml}$ for CE, fractions (EtOAc, FW) and subfractions (F1-F12) against all the yeasts tested. On the other hand, the subfractions (F13-F22) showed good or moderate antifungal activity against $C$. albicans and $C$. parapsilosis but no activity against $C$. krusei and C. tropicalis. Against C. albicans and $C$. parapsilosis, the subfractions F13-F22 showed a MIC of $31.5 \mu \mathrm{g} / \mathrm{ml}$ to $125 \mu \mathrm{g} / \mathrm{ml}$. The fungicidal action was moderate for subfractions F13-F18 $(125-250 \mu \mathrm{g} / \mathrm{ml})$ and for the subfractions F21 and F22 $(125 \mu \mathrm{g} / \mathrm{ml})$ against $C$. albicans. Whereas against C. parapsilosis, only as subfractions F21 and F22 $(125 \mu \mathrm{g} / \mathrm{ml})$ showed moderate fungicidal activity, in accordance with the proposal of Holetz et al. (2002) (Table 1).

Laks (1987) studied the antifungal activity of flavonoids derived from a thiolysis reaction with alkyl thiol resulting in epicatechin-4-alkylsulphides. This compound showed a MIC greater than 500 ppm for fungal and gramnegative bacteria. Extracts from the bark of Bridelia ferruginea Benth. were tested at a concentration of $5 \mu \mathrm{g} / \mathrm{ml}$ against Staphylococcus aureus, C. albicans, Staphylococcus epidermidis, Escherichia coli and Streptococcus lactis. For Proteus vulgaris, Proteus mirabilis, Streptococcus pyogenes and Klebsiella sp. the inhibition zone was measured at between 4 and $20 \mathrm{~mm}$, whereas the control antibiotic chloramphenicol produced zones between 15 and $36 \mathrm{~mm}$. Preliminary phytochemical analysis of plant extracts indicated the presence of phenols and tannins (Irobi et al., 1994). Gülçin et al. (2003) studied antioxidant and antimicrobial activity of extracts from the seeds of Pimpinella anisum L. in nine species of bacteria and one species of fungus, and observed strong activity against $S$. aureus. The extracts showed strong antioxidant activity, reducing potential, radical DPPH and oxidate anion scavenging, hydrogen peroxide scavenging, and metal chelating activity, compared with several standards such as BHA, BHT and tocopherol. Chattopadhyay et al. (2001) evaluated the antimicrobial activity of a crude extract from leaves of Alstonia macrophylla Wall, against S. aureus, Staphylococcus saprophyticus, Steptococcus faecalis, E. coli, P. mirabilis, Trichophyton rubrum, Trichophyton mentagrophytes var. mentagrophytes and Microsporum gypseum, which showed MIC 64-1,000 $\mu \mathrm{g} / \mathrm{ml}$ and $32-128 \mu \mathrm{g} / \mathrm{ml}$ for dermatophytes. However, these extracts were inactive against other microorganisms. Studies with $S$. adstringens (Mart.) Coville by Toledo (2002) demonstrated that subfractions of the EtOAc fraction of the stem bark showed antibacterial activity against gram-positive ( $S$. aureus and Bacillus subtilis) and gram-negative (Pseudomonas aeruginosa and E. coli) bacteria; one subfraction (F3\#12) showed the best activity against $P$. aeruginosa. Lopes et al. (2003), in studies with Stryphnodendron polyphyllum Mart., observed activity against $S$. aureus in fractions 15 and 9, which showed a MIC of $125 \mu \mathrm{g} / \mathrm{ml}$ and a minimum bactericidal concentration of $125-250 \mu \mathrm{g} / \mathrm{ml}$.

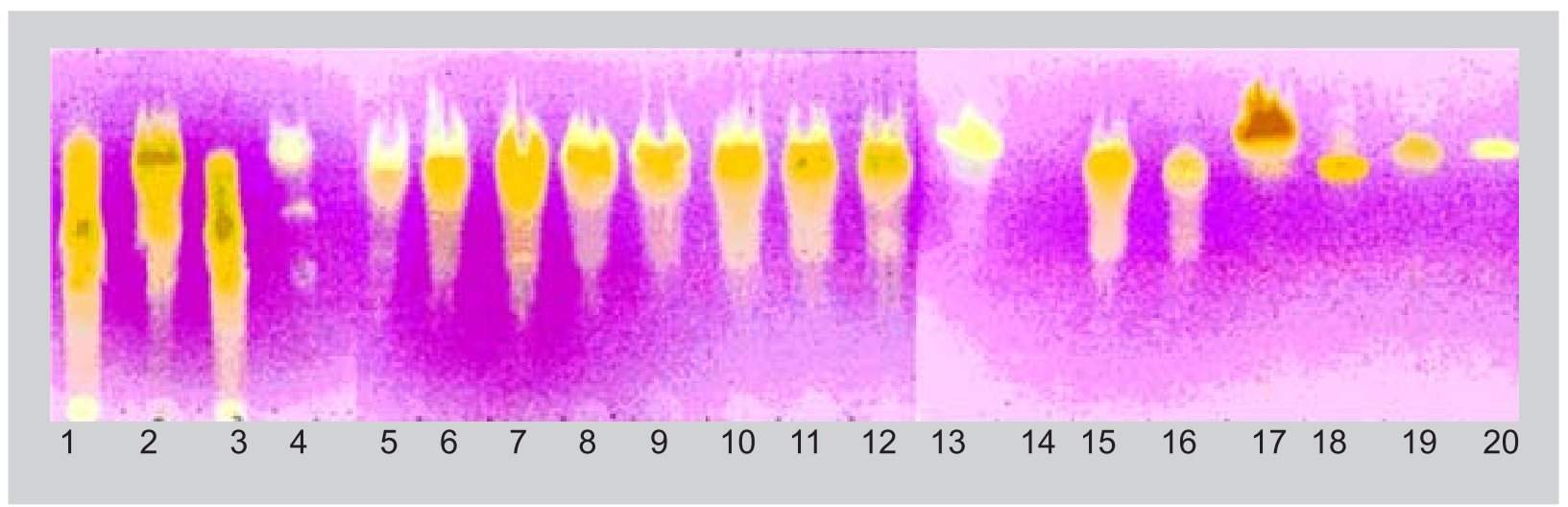

FIGURE 1 - Antioxidant activity of crude extract, fractions, subfractions and isolated compounds from Stryphnodendron obovatum on DPPH radical. 1. CE, 2. EtOAc, 3. FW, 4. F2, 5. F3, 6. F5-7, 7. F8, 8. F9, 9. F10, 10. F11, 11. F12, 12. Compound I, 13. Compound II, 14. not sampled, 15. Compound III, 16. F11.3, 17. quercetin, 18. rutin, 19. gallic acid, 20. astilbin 
TABLE 1 - Minimal inhibitory concentration (MIC) and minimal fungicidal concentration (MFC) of crude extract, fractions, subfractions and compounds isolated from $S$. obovatum against yeasts

\begin{tabular}{lcccc}
\hline & & \multicolumn{2}{c}{ MIC (MFC) $\boldsymbol{\mu g} / \mathbf{m l}$} \\
& C. albicans & C. parapsilosis & $\boldsymbol{C}$. krusei & C. tropicalis \\
\hline Crude extract & $>1000(>1000)$ & $>1000(>1000)$ & $>1000(>1000)$ & $>1000(>1000)$ \\
Water fraction & $>1000(>1000)$ & $>1000(>1000)$ & $>1000(>1000)$ & $>1000(>1000)$ \\
Ethyl-acetate fraction & $>1000(>1000)$ & $>1000(>1000)$ & $>1000(>1000)$ & $>1000(>1000)$ \\
F1 to F12 & $>1000(>1000)$ & $>1000(>1000)$ & $>1000(>1000)$ & $>1000(>1000)$ \\
F13 & $125(250)$ & $125(1000)$ & $>1000(>1000)$ & $>1000(>1000)$ \\
F14 & $125(250)$ & $125(500)$ & $>1000(>1000)$ & $>1000(>1000)$ \\
F15 & $125(125)$ & $62.5(500)$ & $>1000(>1000)$ & $>1000(>1000)$ \\
F16 & $62.5(125)$ & $62.5(1000)$ & $>1000(>1000)$ & $>1000(>1000)$ \\
F17 & $62.5(125)$ & $31.5(1000)$ & $>1000(>1000)$ & $>1000(>1000)$ \\
F18 & $62.5(125)$ & $31.5(500)$ & $>1000(>1000)$ & $>1000(>1000)$ \\
F19 & $62.5(1000)$ & $62.5(500)$ & $>1000(>1000)$ & $>1000(>1000)$ \\
F20 & $125(500)$ & $125(500)$ & $>1000(>1000)$ & $>1000(>1000)$ \\
F21 & $62.5(125)$ & $62.5(125)$ & $>1000(>1000)$ & $>1000(>1000)$ \\
F22 & $62.5(125)$ & $62.5(125)$ & $>1000(>1000)$ & $>1000(>1000)$ \\
Compound I & $>100(>100)$ & $>100(>100)$ & $>100(>100)$ & $>100(>100)$ \\
Compound II & $>100(>100)$ & $>100(>100)$ & $>100(>100)$ & $>100(>100)$ \\
Compound III & $>100(>100)$ & $>100(>100)$ & $>100(>100)$ & $>100(>100)$ \\
Nystatin & $1(-)$ & $8(-)$ & $4(-)$ & $8(-)$ \\
\hline
\end{tabular}

Condensed tannins are usually isolated in a Sephadex ${ }^{\circledR}$ LH-20 column, mainly with alcoholic solvents, to separate first the monomeric, and next the di-, tri-, and oligomeric flavan-3-ols (Thompson et al., 1972). The present study demonstrated the presence of fungicidal activity against $C$. albicans and $C$. parapsilosis, in subfractions F13 to F22. These subfractions may be compounds of higher molecular weight than subfractions F1 to F12, which could account for the greater activity of the former. Greater activity of high-molecular-weight compounds was observed previously by Holetz (2003) in a trypanosomatid protozoan, using CE and EtOAc subfractions from $S$. adstringens (Mart.) Coville.

The antifungal activity of the subfractions F13-F22 on $C$. albicans and $C$, parapsilosis may result from the properties of bark tannins, such as: extracellular enzyme inhibition, deprivation of substratum, inhibition of oxidative phosphorylation, as well as mechanisms that involve deprivation of iron (Scalbert, 1991).

The subfractions (F8 and F10) obtained from EtOAc fraction chromatography on Sephadex ${ }^{\circledR}$ LH-20 column were rechromatographed under the same conditions. The compounds I, II, and III were isolated and identified as epigallocatechin, gallocatechin, and epigallocatechin$(4 \beta \rightarrow 8)$-gallocatechin, respectively, using ${ }^{1} \mathrm{H} \mathrm{NMR},{ }^{1} \mathrm{H} /$ ${ }^{1} \mathrm{H}$ COSY, and mass spectroscopy and polarimetry, and comparing their data with the literature (Fig. 2). Although these substances have previously been isolated from Psidium guajava L. (Myrtaceae) (Tanaka et al., 1992), Cistus incanus L. (Cistaceae) (Petereit, 1992) and S. adstringens (Mart.) Coville (Mello et al., 1996), this is the first time that they have been isolated from $S$. obovatum. These compounds, at concentration of $10 \mu \mathrm{g} / \mathrm{ml}$, showed capacity of scavenging the DPPH radical, indicating antioxidant activity. On the other hand, the compounds I, II and III showed no antifungal activity as observed for subfractions F8 and F10.

\section{CONCLUSIONS}

From the mixture of compounds from the EtOAc, the following compoundswere isolated and identifued epigallocatechin, gallocatechin, and epigallocatechin$(4 \beta \rightarrow 8)$-gallocatechin using ${ }^{1} \mathrm{H}$ RMN,${ }^{1} \mathrm{H} /{ }^{1} \mathrm{H}$ COSY, mass spectroscopy and polarimetry, and comparing their data with the literature. The results demonstrated that the extracts, fractions and subfractions all possessed antioxidant activity. In particular, fractions F5-F12 showed high activity compared to the quercetin, rutin, gallic acid and astilbin controls. The present study demonstrated the presence of fungicidal activity against $C$. albicans and $C$. parapsilosis in subfractions F13 to F22. These 


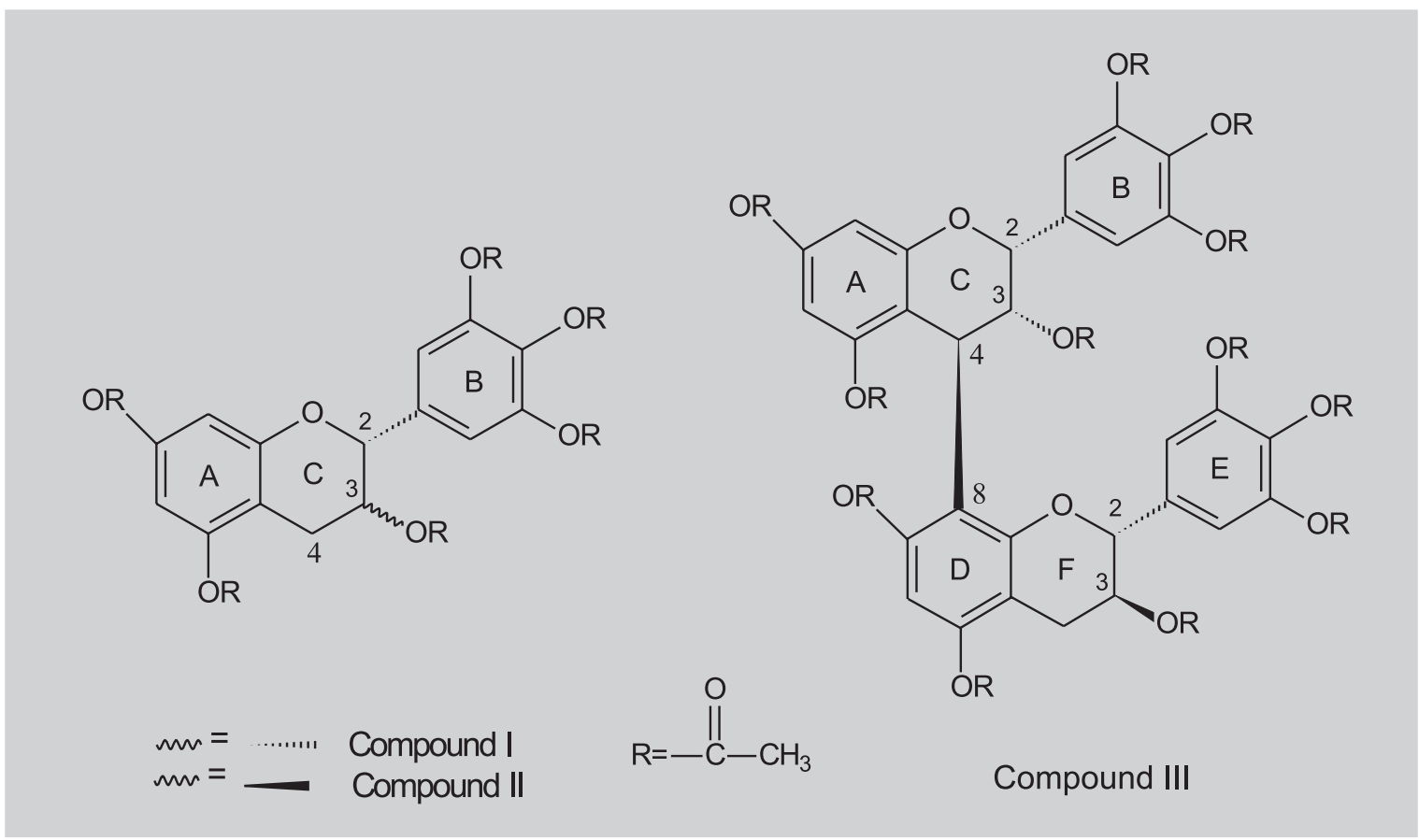

FIGURE 2 - Chemical structure at the isolated compounds

subfractions may be compounds of higher molecular weight than subfractions F1 to F12, which could account for the greater activity of the former.

\section{ACKNOWLEDGMENTS}

This study was supported through grants of the Conselho Nacional de Desenvolvimento Científico e Tecnológico-CNPq. To M. Martinez-Vicentim for help in the experiments and to A. Arantes for technical assistance.

\section{RESUMO}

\section{Atividades antioxidante e antifúngica de extratos e taninos condensados de Stryphnodendron obovatum Benth.}

Atividade antioxidante de extrato, frações, subfrações e substâncias isoladas das cascas de Stryphnodendron obovatum Benth. foi avaliada através da redução do radical 1,1-difenil-2-picrilhidrazila (método DDPH) em cromatografia em camada delgada. O extrato bruto (CE, acetona:água), as frações acetato de etila (EtOAc) e aquosa (FW), as subfrações (F1-F12) e as substâncias isoladas I, II e III apresentaram a capacidade de reduzir o radical DDPH: A atividade antifúngica foi determinada pela concentração inibitória mínima (CIM) e concentração fungicida mínima
(CFM) frente às amostras de leveduras Candida albicans, Candida parapsilosis, Candida krusei $e$ Candida tropicalis. O extrato bruto (CE), as frações (EtOAC e $F W$ ), e os compostos isolados I, II e III, como também as subfrações cromatográficas (F1-F12) foram inativos frente a todas as leveduras testadas. Por outro lado, as subfrações cromatográficas F13-15 e F20 apresentaram atividade antifúngica moderada. Já as subfrações F16-19 e F21-22 mostraram boa atividade antifúngica frente às cepas de $\mathrm{C}$. albicans $e \mathrm{C}$. parapsilosis. As substâncias I, II, e III, isoladas da fração EtOAc por cromatografia e recromatografia em coluna de Sephadex ${ }^{\circledR}$ LH-20, foram identificadas como sendo os monômeros de flavan-3-ol, epigalocatequina e galocatequina, e um dimero, epigalocatequina$(4 \beta \rightarrow 8)$-galocatequina, respectivamente.

UNITERMOS: Stryphnodendron obovatum. Leguminosae. Atividade antioxidante. Atividade antifúngica. Taninos condensados.

\section{REFERENCES}

BORS, W.; MICHEL, C.; STETTMALER, K. Electron paramagnetic ressonance studies of radical species of proanthocyanidins and gallate esters. Arch. Biochem. Biophys., New York, v.374, n.2, p.347-355, 2000. 
CHATTOPADHYAY, D.; MAITI, A.P.; KUNDU, M.S.; CHAKRABORTY, R.; BHADRA, R.; MANDAL, S.C.; MANDAL,A.B. Antimicrobial activity of Alstonia macrophylla: a folklore of Bay Island. $J$. Ethnopharmacol., Leiden, v.77, p.49-55, 2001.

CRONQUIST, A. The evolution and classification of flowering plants. 2nd.ed., New York: The New York Botanical Garden, 1988. p. 261-449.

CUENDT, M.; HOSTETTMAN, K.; POTTERAT, O. Iridoid glucosides with free radical scavenging properties from Fagraea blumei. Helv. Chim. Acta, Basel, v. 80, p.1144-1152, 1997.

DEMIREZER, Ö.L.; UZ-KURUÜZÜM, A.; BERGERE, I.; SCHIEWE, H.-J.; ZEECK, A. The structures of antioxidant and citotoxic agents from natural source: anthraquinones and tannins from roots of Rumex patientia. Phytochemistry, New York, v.58, p.1213-1217, 2001.

FOO, L.Y.; HOWELL, A.B.; VORSA, N. The structure of cranberry proanthocyanidins which inhibit adherence of urophatogenic P-fimbirated Escherichia coli in vitro. Phytochemistry, New York, v.54, p.173-181, 2000.

GÜLÇIN, I.; OKTAI, M.; KIREÇCI, E.; KÜFREVIOGLU, I. Screening of antioxidant and antimicrobial activities of anise (Pimpinella anisum L.) seed extracts. Food Chem., v.83, p.371-382, 2003.

HASLAM, E. Practical polyphenolics: from structure to molecular recognition and physiological action. Cambridge: Cambridge University Press, p.307-315, 1998.

HATANO, T.; MIYATAKE, H.; NATSUME, M.; OSAKABE, N.; TAKIZAWA, T.; ITO, H.; YOSHIDA, T. Proanthocyanidin glycosides and related polyphenols from cacao liquor and their antioxidant effects. Phytochemistry, New York, v.59, p.749-758, 2002.

HEMINGWAY, R.W.; FOO, L.Y.; PORTER, L.J. Linkage isomerism in trimeric and polymeric 2,3-cis-procyanidins. J. Chem. Society, Perkins Trans. I, London, p.12091216, 1982.
HOLETZ, F.B. Efeito de extratos de plantas no crescimento, diferenciação e ultraestrutura de Herpetomonas samuelpessoai. Maringá, 2003. 81 p. [Dissertação de Mestrado em Ciências Farmacêuticas, Universidade Estadual de Maringá].

HOLETZ, F.B.; PESSINI, G.L.; SANCHES, N.R.; CORTEZ, D.A.G.; NAKAMURA, C.V.; DIAS FILHO, B.P. Screening of some plants used in the Brazilian folk medicine for the treatment of infectious diseases. Mem. Inst. Oswaldo Cruz, Rio de Janeiro, v.97, n.7, p.10271031, 2002.

HOSTETTMANN, K.; QUEIROZ, E.F.; VIEIRA, P.C. princípios ativos de plantas superiores. São Carlos: EdUFSCar, 2003. p.54.

IROBI, O.N.; MOON-YONG, M.; ANDERSON, W.A.; DARAMOLA, S.A. Antimicrobial activity of bark extracts of Bridelia ferruginea (Euphorbiaceae). $J$. Ethnopharmacol., Leiden, v.43, p.185-190, 1994.

LAKS, P.E. Flavonoid biocides: phytoalexin analogues from condensed tannins. Phytochemistry, New York, v.26, n.6, p.1617-1621, 1987.

LOPES, G.C.; NAKAMURA, C.V.; DIAS FILHO, B.P.; MELLO, J.C.P. Estudo físico-químico, químico e biológico de extratos de cascas de Stryphnodendron polyphyllum Mart., Leguminosae. Rev. Bras. Farmacogn., Maringá, v.13, supl.2, p.24-27, 2003.

MELLO, J.C.P. Untersuchung zur Struktur der Flavan-3ole und Proanthocyanidine aus der Rinde von Stryphnodendron adstringens (Martius) Coville (Mimosaceae). Münster, 1995. 236 p. [Tese de Doutorado em Ciências Naturais. Universidade Münster].

MELLO, J.C.P; PETEREIT, F.; NAHRDSTEDT, A. A flavan-3-ols and prodelphinidins from Stryphnodendron adstringens. Phytochemistry, New York, v.41, p.807813, 1996.

MELLO, J.C.P.; PETEREIT, F., NAHRDSTEDT, A. A dimeric proanthocyanidin from Stryphnodendron adstringens. Phytochemistry, New York, v.51, p.11051107, 1999. 
NCCLS-National Committee For Clinical Laboratory Standards. Reference method for broth dilution antifungal susceptibility testing of yeasts. $2 \mathrm{nd}$. ed. Approved standard M27-A2, vol.22, \#15. Wayne, Pennsylvania, 2002.

OKAMURA, H.; MIMURA, A.; NIWANO, M.; YOKAHARA, Y. Antioxidant activity of tannins and flavonoids in Eucalipto rostrata. Phytochemistry, New York, v.33, n.3, p.557-561, 1993.

PETEREIT, F. Polyphenoliche Inhaltsstoffe und Untersuchungen zur Entzündungshemmenden Aktivität der traditionellen Arzneipflanze Cistus incanus L. (Cistaceae).. Münster, Alemanha, 1992, 223f. Tese (Doutorado em Ciências Naturais) Universidade Münster.

SANCHES, A.C.C.; MELLO, J.C.P.; NAKAMURA, C.V.; MUNDO, S.R.; SILVA, P.E.R. Pharmacognostic study and antibacterial activity of the stem bark extract Stryphnodendron obovatum Benth, Leguminosae. Rev. Fitoter., Valencia, v.2, n.1, p.301, 2002.

SANTOS, C.A.M.; TORRES, K.R.; LEONART, R. Plantas medicinais (herbarium, flora et scientia). Curitiba: Scientia et Labor, 1987. p.39.

SANTOS, S.C.; MELLO, J.C.P Taninos. In: SIMÕES, C.M.O.; SCHENKEL, E.P.; GOSMANN, G.; MELLO, J.C.P.; MENTZ, L.A.; PETROVICK P.R. Farmacognosia da planta ao medicamento. 5.ed. Porto Alegre/Florianópolis: Editora da URFGS/UFSC, 2004. p.615-656.

SCALBERT, A. Antimicrobial properties of tannins. Phytochemistry, New York, v.30, v.12, p.3875-3883, 1991.
SIMERAY, J.; CHAUMONT, J.P.; BEVALOT, F.; VAQUETTE, I. Les propiétés antifongiques des Cistacées et plus particulièrement de Cistus laurifolius L.: role dês tannins non hydrolysable. Fitoterapia, Milano, v. 53, p. $45-48,1982$.

SIQUEIRA, J.C. Plantas do cerrado na medicina popular. Spectrum-J. Bras. Ci., v.2, p.41, 1982.

TANAKA, T.; ISHIDA, N.; ISHIMATSU, M.; NONAKA, G.; NISHIOKA, I. Tannins and related compounds. CXVI. Six new complex tannins, guajavins, psidins and psiguavin from the bark of Psidium guajava L. Chem. Pharm. Bull., Tokyo, v.40, p.2092-2098, 1992.

THOMPSON, R.S.; JACQUES, D.; HASLAM, E.; TANNER, R.J.N. Plant proantocyanidins. Part 1. Introduction; the isolation, structure, and distribution in nature of plant procyanidins. J. Chem. Soc., Perkin Trans. I, London, p.1387, 1972.

TOLEDO, C.E.M. Estudos anatômico, químico e biológico de cascas e extratos obtidos de barbatimão [Stryphnodendron adstringens (Mart.) Coville, Leguminosae]. Araraquara, 2002, 92f. Dissertação (Mestrado em Ciências Farmacêuticas) Universidade Estadual Paulista.

VELÁZQUEZ, E.; TOURNIER, H.A.; BUSCHIAZZO, P.M.; SAAVEDRA, G.; SCHINELLA, G.R. Antioxidant activity of Paraguayan plant extracts. Fitoterapia, Milan, v.74, p.91-97, 2003.

Recebido para publicação em 02 de junho 2004. Aceito para publicação em 02 de março de 2005. 